\title{
EARLY EVIDENCE OF BOXING IN ANCIENT EGYPT AND MESOPOTAMIA: A COMPARATIVE STUDY
}

\author{
Fawziah Abdullah MOHAMMED \\ Faculty of archaeology, Cairo University, Egypt \\ drfawziahabdullah@gmail.com
}

\begin{abstract}
This paper investigates early evidence of boxing as a sport in Ancient Egypt and Mesopotamia. Its representations were relatively rare in both cultures, because of the essentially static nature of their arts. In addition, it is also difficult to distinguish between wrestlers and boxers. The article examines the differences among early pictorial examples from the two cultures dating to the third and second millennia BCE. This article aims also to answer key questions concerning this sport in both cultures: Which culture did practice the sport first? Which one did borrow this sport from the other? It is worth noting that the evidence of boxing in Mesopotamia was earlier than that originating from Egyptian contexts. Moreover, the origins of boxing in Ancient Egypt are uncertain. The article raises another important question, stating, "Do all images in the article are Boxing Scenes or some of them can be considered as combat training?" Despite the disagreement in both cultures, it can be argued that boxing representation in Mesopotamia is clearer than in Ancient Egypt.
\end{abstract}

\section{KEYWORDS}

Boxing; boxers; Mesopotamia; Ancient Egypt.
الملخص

يهدف المقال إلى مناقشة الأدلة المبكرة على وجود

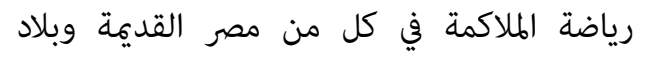

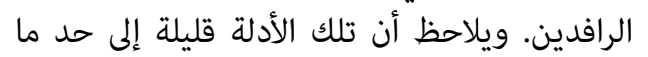

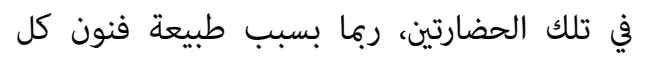

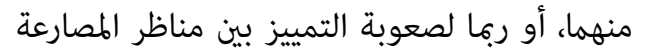

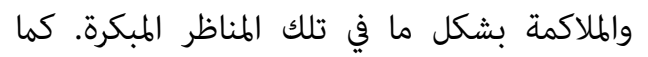

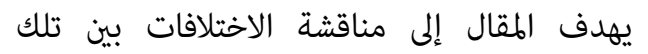

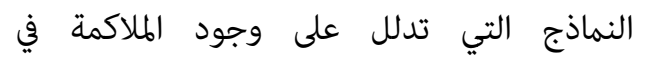

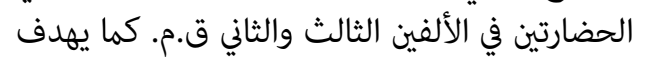
المقال أيضا إلى البحث عن أجوبة ألفئ أهم الأسئلة التي

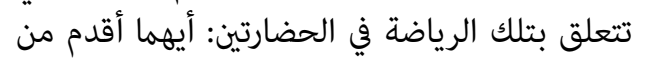

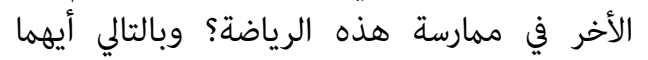

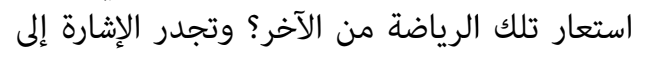

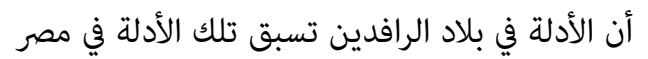

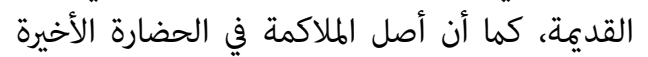

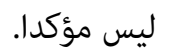

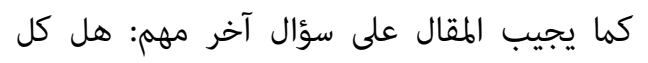

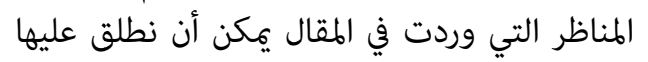

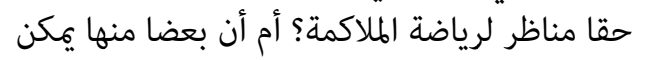

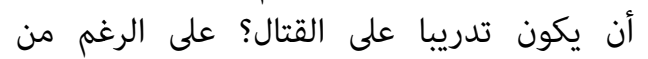
اختلاف الآراء حول بعض آنان مناظر الملاكمة في كلتا الحضارتين، إلا أنها أكثر وضوحا في في بلاد الران الرافدين عنها في مصر القديمة.

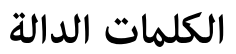
الملاكمة، الملاكمون، بلاد النهرين، مصر القديمة. 


\section{INTRODUCTION}

Boxing was one of the popular sports in the ancient Near East. It was the third selfdefence sport, after wrestling and stock fencing in ancient Egypt. ${ }^{1}$ The evidence for boxing in Egypt is lower than expected.$^{2}$ The earliest physical evidence portraying boxing comes from Mesopotamia, where it is depicted on a few carvings that are believed to date to the third and second millennia BCE. ${ }^{3}$

\section{ANCIENT MESOPOTAMIA}

According to Murry, the origins of boxing as a sport in the ancient Near East can be traced to ancient Mesopotamia. ${ }^{4}$ Carvings dating to the third and second millennia $\mathrm{BCE}^{5}$ prove that Mesopotamia knew boxing centuries before Ancient Egypt. But it is better to leave discussion field open on this issue .

\subsection{LIMESTONE PLAQUE FROM IRAQ MUSEUM, BAGHDAD:}

A plaque including three registers may be one of the obvious scenes of boxing in Mesopotamia .It is dating to the Sumerian Early Dynastic periods, about 3000-2340 BCE, now in the Iraq Museum (No.9012) ${ }^{6}$ (see Figs. 1, 2). The third register depicts two musicians, one playing the harp, as well as two boxers. They are flanked by another figure, identified as a judge or trainer holding a staff. Both boxers are naked except for a cache-sex and gloves. They are standing in the pose, one facing the other, in a manner quite identical to those stances in present-day boxing scenes. ${ }^{7}$ (see Fig. 2)

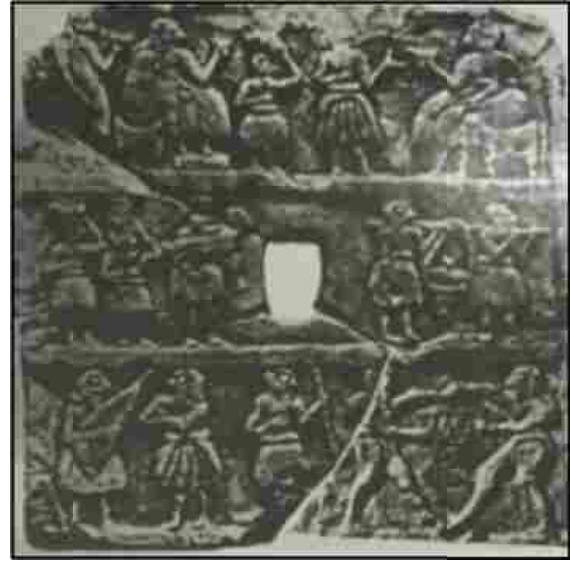

Fig.1: limestone votive plaque, Sumerian Early dynastic periods. (Festuccia 2016: 103, fig.5).

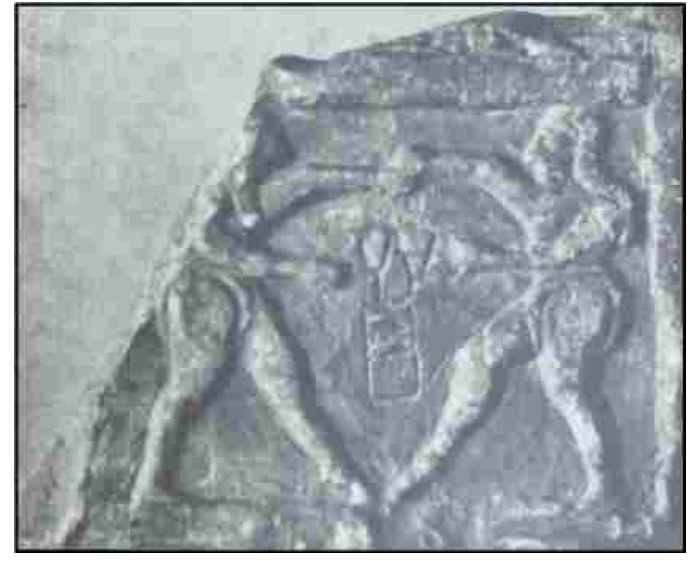

Fig. 2: Details of a limestone plaque (A Guide of the collection in the Iraq Museum, 1937, No. 9012).

\footnotetext{
${ }^{1}$ Decker., " Sport", L $\ddot{A} V, 1162-70$.

2 Tyldesley., "Egyptian Games and Sports," A Shire Egyptology book 29, 49.

${ }^{3}$ Decker., Sport Und Spiel im Alten Ägypten, 78.

4 Murry., Boxing Gloves of the Ancient World, Journal of combative sport, in: https://www.academia.edu/3728745/Boxing Gloves of the Ancient World. pdf.(2010),1.

${ }^{5}$ Decker, Sport und Spiel im alten Ägypten,78.

${ }^{6}$ Department of Antiquities, A Guide of the Collection in the Iraq Museum, No. 9012, fig.13.

${ }^{7}$ Festuccia., Sport Representation: Transfer Images of Agonistic Contests, in International Congress on the Archaeology of proceeding of the $9^{\text {th }}$ International congress on the Archaeology of the Ancient Near East, vol. I, 103-4; fig.5.
} 


\subsection{TERRACOTTA FRAGMENT FROM NINTU TEMPLE, "KHAFAJI", SUMERIAN EARLY DYNASTIC PERIODS}

Divergent interpretations exist for the representations of the fragment of terracotta plaque $^{1}$, levels V and VII, that was discovered in the Nintu temple in "Khafaji", dating back to the Sumerian Early Dynastic periods, about 3000-2340 BCE. Currently, it is preserved at the Iraq Museum (No.9012) (see Fig. 3).

Like the previous tablet (see Figs. 1,2), the right of this scene shows two athletes facing each other and holding each other by the arms. In the central scene the athlete on the left has lost his balance and is falling to the ground, as his opponent appears to have knocked him off by grasping his leg. ${ }^{3}$ According to Orthmann and Festuccia, these would be two wrestlers. ${ }^{4}$ Murry surmised that the two individuals on the right are boxers. ${ }^{5}$

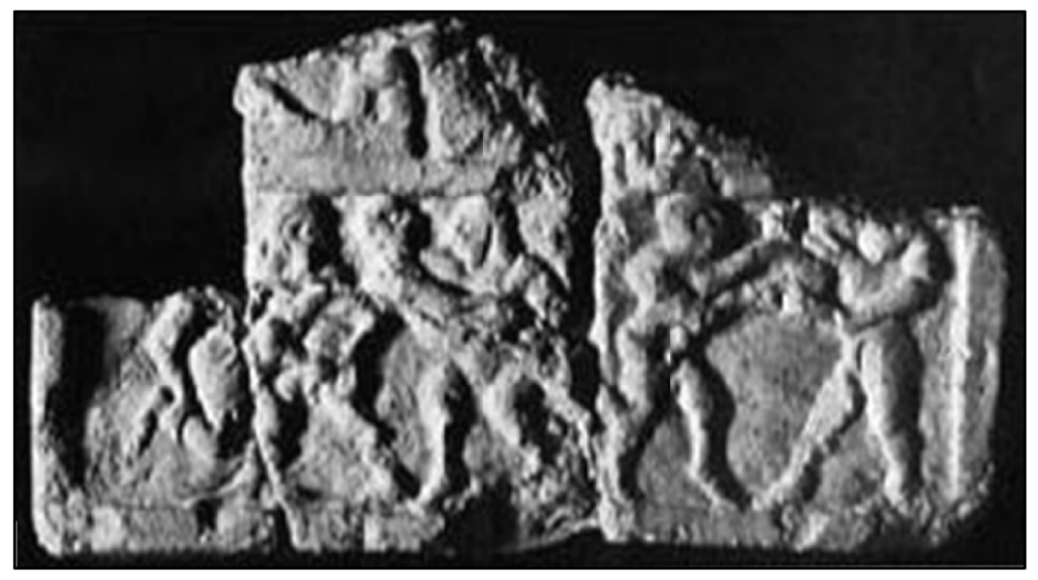

Fig. 3: Terracotta relief from Khafaji with two boxers on the right, Iraq Museum, Baghdad

(Murry 2010: fig. 1)

\subsection{TERRACOTTA RELIEF FROM ESHNUNNA (MODERN TELL ASMER)}

This terracotta relief from Eshnunna (modern Tell Asmer)(see map.1), which dates to the Old Babylonian period (2000-1595 BCE) (Fig. 4), depicts two boxers who are bearded and wear tunics. They are facing each other with their arms bent and fists clinched. fists clinched, in the position of defense. The boxers are not wearing gloves, but they do have straps or bands around their wrists, for support and protection. ${ }^{6}$

\footnotetext{
${ }^{1}$ It is $24.5 \mathrm{~cm}$ wide.

${ }^{2}$ Moortgat., Art in Ancient Iraq, translated into Arabic by Essa Salman and Salim Taha Al-Takriti, 9192.

${ }^{3}$ Festuccia.,"Sport Representation: Transfer Images of Agonistic Contests", 104, fig.6.

${ }^{4}$ Orthmann., Der Alte Orient, PKG 14,187; abb.81b.

Festuccia.,"Sport Representation: Transfer Images of Agonistic Contests", 104; fig.6.

${ }^{5}$ Murry.,"Boxing Gloves of the Ancient World", 2, fig.1

${ }^{6}$ Murry.,"Boxing Gloves of the Ancient World", 2, fig.2.
} 


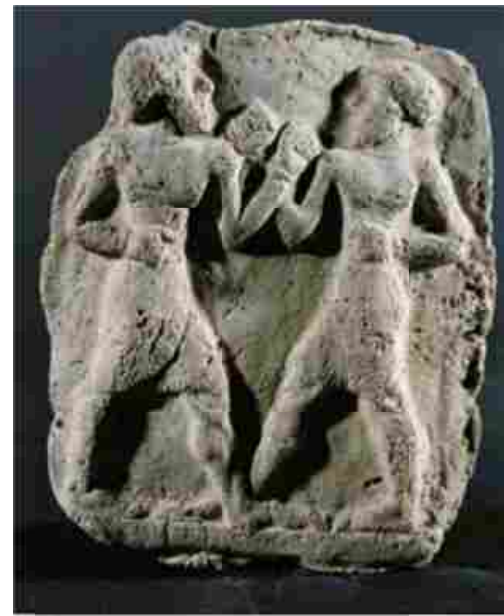

Fig.4: Terracotta relief from Eshnunna, boxers with gloves, Old Babylonian period (2000-1595 BCE) (Murry 2010: Fig. 2).

\subsection{TERRACOTTA RELIEF FROM LARSA ( MODERN TELL SINKARA), OLD BABYLONIAN PERIOD}

Another terracotta tablet depicts two men boxing, wearing caps and tunics (Fig. 5). It dates back to Old Babylonian period (2000-1595 BCE). It was found in a tomb at Larasa (modern Senkereh or Tell as-Senkereh تل السنكرة), in southern Iraq ${ }^{1}$.(See map 1) It is preserved in British Museum (BM 91906). ${ }^{2}$ The boxers are bare knuckled. ${ }^{3}$ The boxers are represented with musicians playing instruments; ${ }^{4}$ a sitting figure on the left left plays a drum, and a standing one on the right beats' clappers together. It is known that games were accompanied by music in the ancient Near East, such as bull leaping. ${ }^{5}$

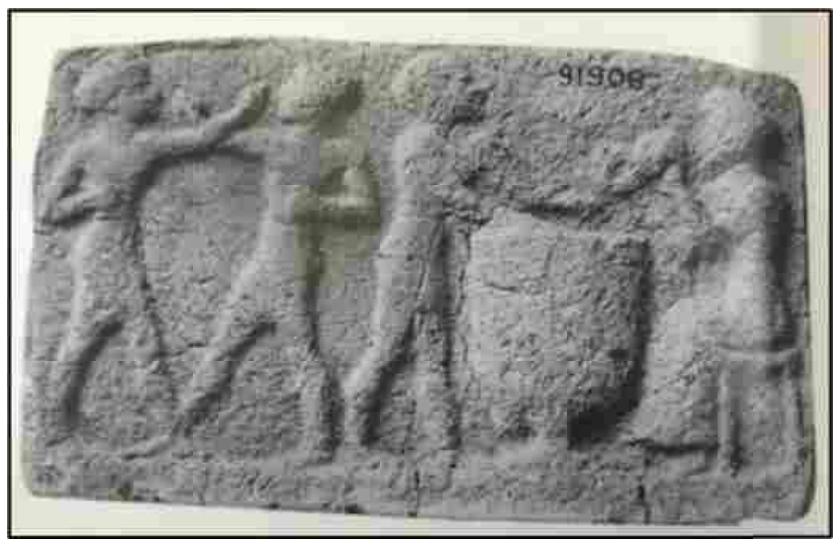

Fig. 5: Two Boxers with two men playing drum and clappers (Murry 2010: Fig. 3).

\footnotetext{
${ }^{1}$ It lies some 25 km southeast of Uruk in Iraq's Dhi Qar ذب قار Governorate, near the east bank of the Shatt-en-Nil canal at the site of the modern settlement Tell as-Senkereh or Sankarah.

${ }^{2}$ It is $7 \mathrm{~cm}$ high and 11.5 wide.

${ }^{3}$ Murry.,"Boxing Gloves of the Ancient World", 2; fig.3

${ }^{4}$ Bienkowski\& Millard., "Sport", in British Museum Dictionary of the Ancient Near East, 276-77.

${ }^{5}$ Rolling.,"Sport Und Spiel" in: Erich, E.\& Friedrich (eds.), Reallexikon der Assyriologie, und vorderasiatischen Archäologie, band 13, 8.
} 


\section{ANCIENT EGYPT}

The mastaba of Ptahhotep II, at Saqqara, contains the oldest depiction of boxing training in ancient Egypt ${ }^{1}$. The New Kingdom tomb of Kheruef (TT 192), shows kilted bare-knuckled boxers participating alongside other martial artists in the celebration of raising the Djed-pillar. ${ }^{2}$ A contemporary pair of figures in the Amarna tomb of Meryre II may also be boxers ${ }^{3}$. The boxers' gloves did not appear in Egyptian dynastic periods. However, they appeared in a representation of a cat and mouse fighting, dating to the Greek-Roman period,

\subsection{THE MASTABA OF PTAHHOTEP, FIFTH DYNASTY (2560-2420 BCE)}

On the south wall of the offering room of the mastaba of Ptahhotep II at Saqqara, dating back to Old Kingdom Fifth Dynasty. The deceased Ptahhotep II depicts twice to observe activities on his estate, including harvesting of papyrus, dancing, games, hunting, fishing, etc. (Fig. 6). ${ }^{4}$ In the second register, two boys are standing together, each with an arm around the other's neck and holding his other arm around his fellow; they appear to be going in opposite directions and each perhaps was attempting to free his own arm. ${ }^{5}$ There was no hieroglyphic caption to the scene. Although this scene was part of a larger representation of wrestling figures and players, it showed two men training for a fight. Here, the men are training for a free fight, with hands and legs. This may be the oldest evidence of boxing training in Ancient Egypt. If true, this means that Egypt and Mesopotamia might knew boxing concurrently. According to the available evidence, the fact remains that this sport was practiced in Mesopotamia centuries before Ancient Egypt. We cannot determine if boxing as a sport was imported from Mesopotamia to Egypt. The author leaves it open for discussion.

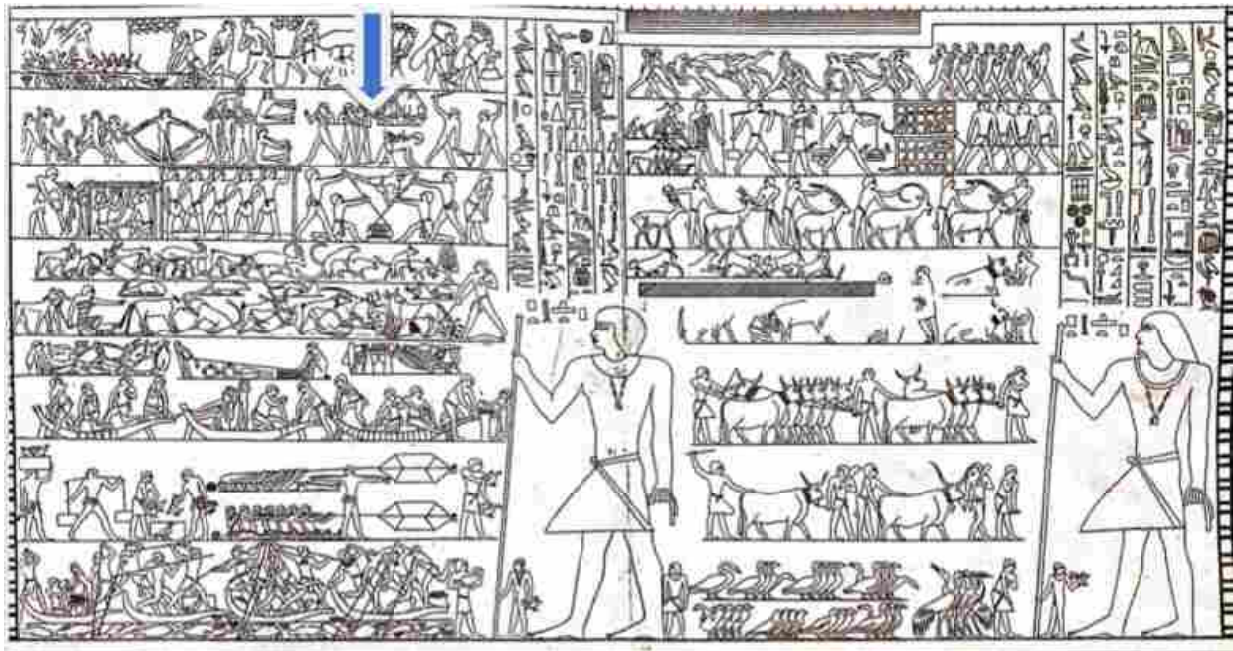

Fig. 6: South wall of offering-room of the mastaba of Ptahhotep II at Saqqara (D64), Fifth Dynasty; two men fighting like boxers on the second row from the left (under the arrow) (Davies 1900: pl.xxi, xxiiia)

\footnotetext{
${ }^{1}$ Dodson \& Ikram., The Tombs in Ancient Egypt, 68.

${ }^{2}$ Caminos., JEA 71, (1985) ,197-200.

${ }^{3}$ Davies., The Rock Tombs of El-Amarna, part II, 34; pl. xxxviii

${ }^{4}$ Dodson \& Ikram., The Tombs in Ancient Egypt, 68.

${ }^{5}$ Davies., The Mastaba of Ptahhotep and Akhehotep at Saqqara, part I,10.
} 


\subsection{THE TOMB OF KHERUEF (TT 192), EL-ASSASIF, REIGN OF AMENHOTEP III (1390-1352 BCE)}

The tomb of Kheruef, TT 192 in the Theban necropolis, was one of the largest eighteenth dynasty private tombs. ${ }^{1} \mathrm{~W}$. Decker and F. Foster believe that this tomb is the only source showing boxing in ancient Egypt. ${ }^{2}$ However, H. Wilsdorf categorises the men as wrestlers ${ }^{3}$ (Figs. 7-9).

The three lower registers have processions of offering bearers and dancers; games are also performed, which were all part of the celebrations of the third Sed festival of Amenhotep $\mathrm{III}^{4}$ (Fig. 7). There are six pairs of boxers, divided into two groups, with the depiction of fighters of stick fencing. They are associated with the ritual of the erection of Djed-pillar.

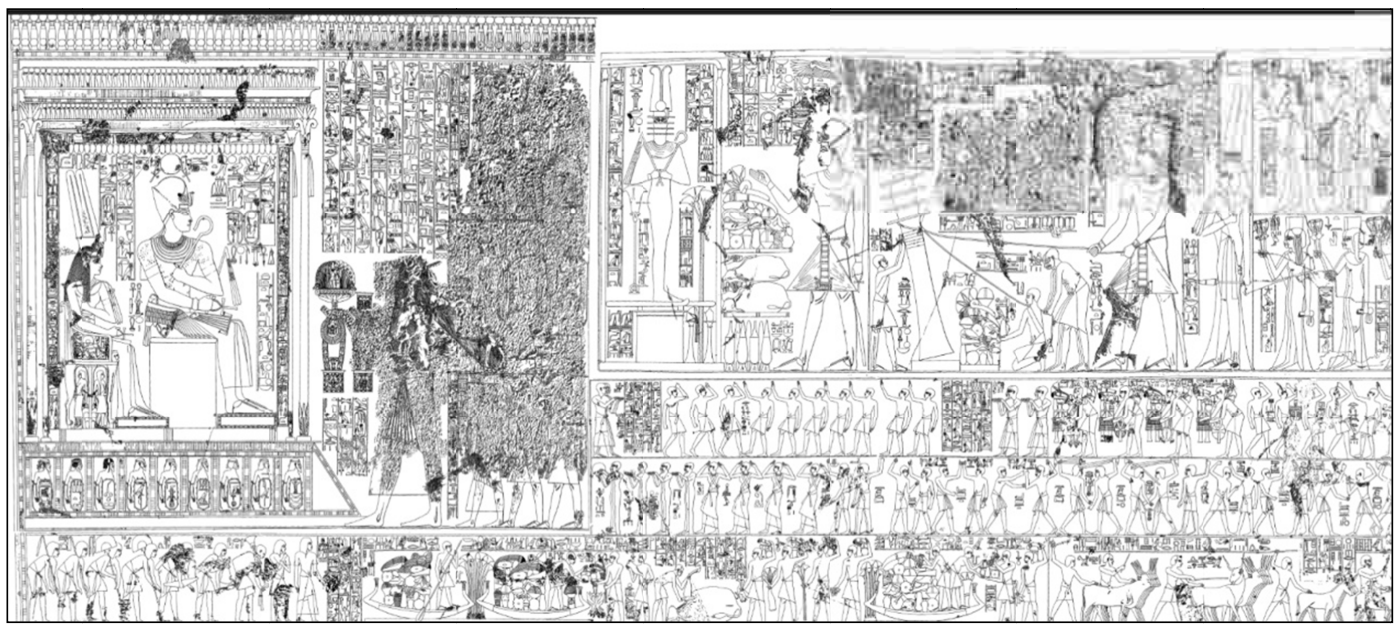

Fig. 7: Scene from the tomb of Kheruef (TT 192), celebration of the third Sed festival of Amenhotep III, Eighteenth Dynasty (The Tomb of Kheruef, Theban Tomb 192, OIP 102, Chicago,1980, pl.47).

All of the boxers had short hair and wore short kilts. They are shown in various combat stances with their hands balled into fists, some poses being repeated ${ }^{5}$ (Fig. 8).

In his analysis of the hieroglyphic text accompanying the boxers, C. A. De Vries concluded from the attitude of the boxers that the word " $n \underline{d} r{ }^{\prime \prime}$ must refer to an aggressive action, and he translated the term as "to strike". ${ }^{6}$ The other term " $n m t^{\prime \prime}$, which occurs six times, is clearly associated with a defensive position, meaning "to protect". De Vries suggests that the statement (it $\left.n h \underline{h r} h^{\top}-m-m 3^{\top} t\right)$, which occurs five

\footnotetext{
${ }^{1}$ PM. I, 298-300; Caminos., JEA 71,197-200.

${ }^{2}$ Decker \& Foster., Annotierte Bibliograghie Zum Sport im Alten Ägypten II:1978-2000, im: Nikephoros Beihefte 8, Berlin, (2002), 94

${ }^{3}$ Decker., Sports and Games of Ancient Egypt, Sport and History Series, Translated by Allen Guttmann, 89 .

${ }^{4}$ The Epigraphic Survey, The Tomb of Kheruef, Theban Tomb 192, OIP 102, pl. 47, 61-63. (http://oi.uchicago.edu).

${ }^{5}$ Decker \& Herb \& Brill, Bildatlas zum Sport im Alten Ägypten, Corpus der bildlichen Quellen zu Leibsübungen, Teil.1,2, Handbuch Der Orientalistik 14,572-3, Taf. cccxxii, N.1,2; Decker \& Tuillier, Le Sport Dans L’Antiquité, Egypt, Grèce et Rome, Antiqua 8, 47.

${ }^{6}$ The Epigraphic Survey, The Tomb of Kheruef, Theban Tomb 192, OIP 102, pl.47;61-63. in : https://oi.uchicago.edu/research/publications/oip/tomb-kheruef-theban-tomb-192 .; Griffiths, JEA 62, (1976) , 186-187, in: (https://www.jstor.org/journal/jegyparch) .
} 
times in the scenes and translates as "brought for Horus, who appears in truth "Amenhotep III", indicates that these ceremonial games of boxing group were performed in honour of the king. De Vries refers also to the expression " $n n$ hft.k", which appears before the second pair of priests, without an obvious connection between the priest and the boxers. He translated it as there is not the opponent "you do not have an opponent".

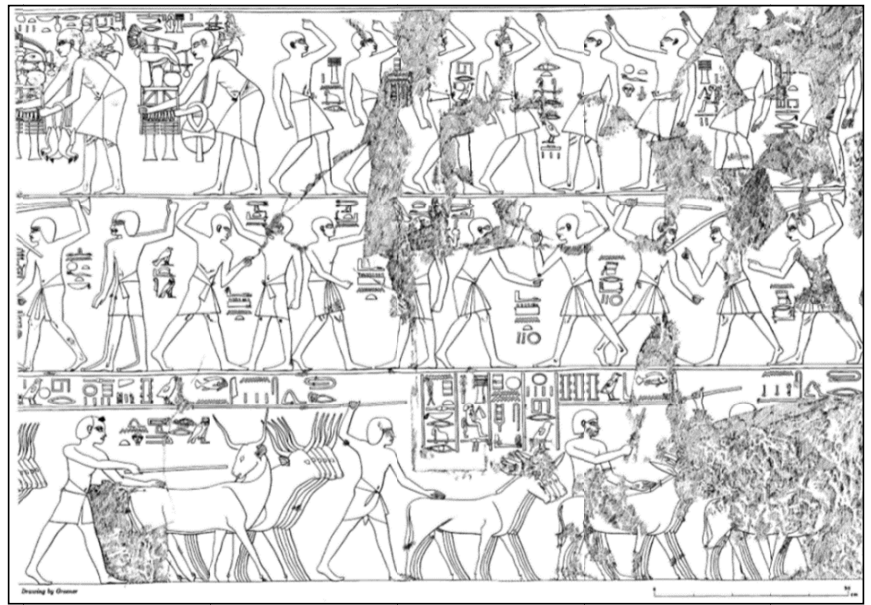

Fig. 8: Scene of boxers in the second row, from the tomb of Kheruef (TT 192) (The Tomb of Kheruef, Theban Tomb 192, OIP 102, Chicago, 1980, pl.61.

De Vries and Decker thought that the twelve boxers continued as if it was a cinematic scene. It is noteworthy that the boxers do not have gloved hands as boxers did in the Mesopotamian culture. ${ }^{2}$ This action depicted in the tomb of Kheruef (TT 192) may be the oldest clear "Boxing scene" in Ancient Egypt (Fig. 9). However, Touny did not thought that these scenes represented true boxing matches, suggesting that they were performances of ritual scenes connected with the celebration of the third Sed festival of Amenhotep III. ${ }^{3}$

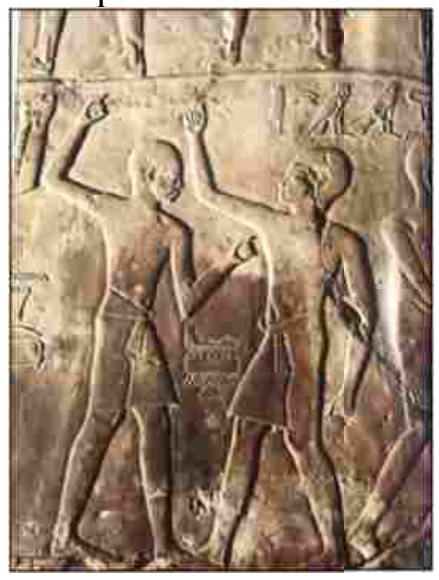

Fig. 9: details of Scene of boxers from the tomb of Kheruef (Decker, W. 1993. Sports and Games of Ancient Egypt, abb.73)

\footnotetext{
${ }^{1}$ De Vries., Attitudes of the Ancient Egyptians toward physical-recreative activities, in: UMI dissertation services (A Dissertation Submitted to the Faculty of Humanities in Candidacy for the degree of Doctor of Philosophy Department of Oriental Languages and Civilizations), 222-39.

2; Decker, Pharao und Sport, Zaberns Bildbände zur Archäologie, 76-7; abb.73,74. De Vries, Attitudes of the Ancient Egyptians toward Physical-Recreative Activities,222-39

${ }^{3}$ Touny, Der sport im Alten Ägypten, International Olympic Editions, 195.
} 


\subsection{THE TOMB OF MERYRE II - TELL EL-AMARNA - REIGN OF " AKHENATEN" (1394-1369 BCE)}

Meryre II, dating to the reign of King Akhenaten, was a royal scribe, steward, and overseer of the royal harem of the great royal wife Nefertiti. ${ }^{1}$ In his tomb, there potential scene of boxers, being part of a reception of foreign tribute showing the king Akhenaten (1394-1369 BCE) (Fig. 10). ${ }^{2}$

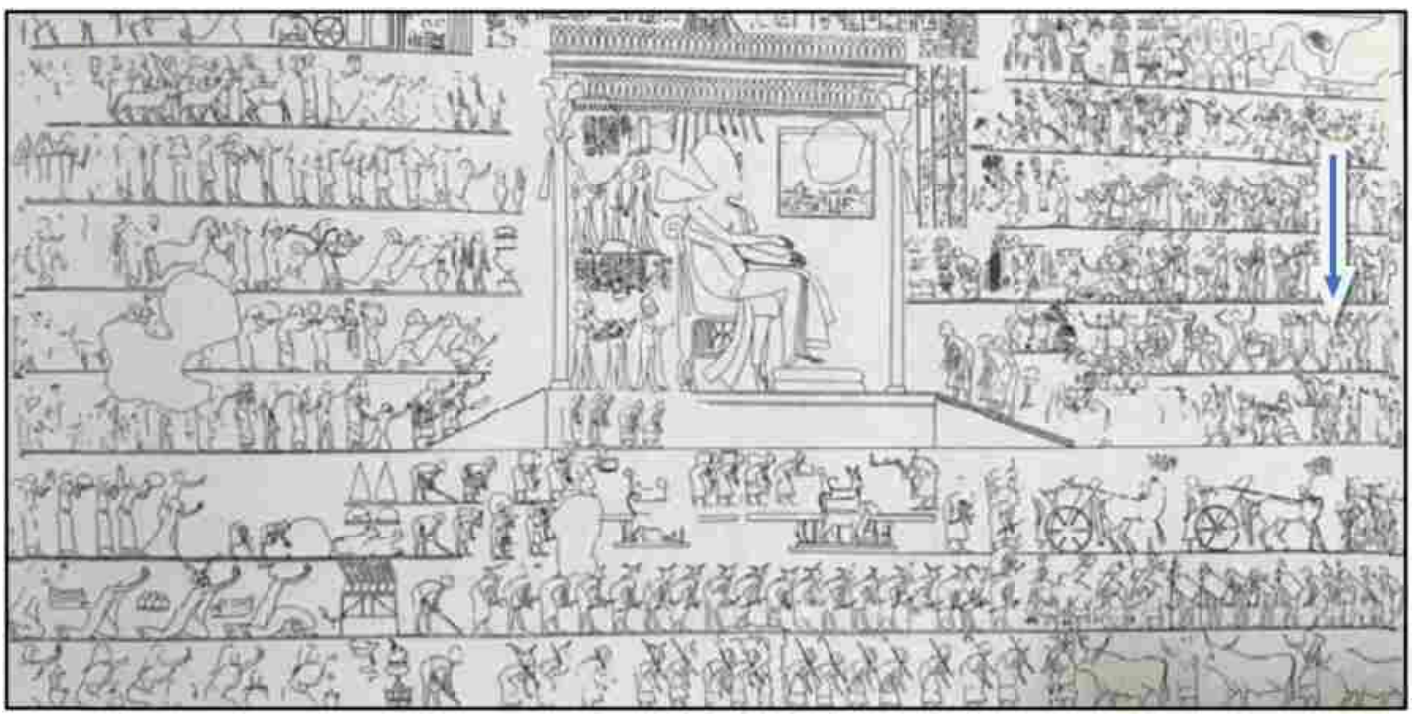

Fig. 10: Reception of foreign tributes by King Akhenaten in tomb of Meryre II, potential boxers under the arrow, Amarna (Gnirs 2009: 31, Fig. 2).

According to Saleh ${ }^{3}$ and Decker \& Thuillier, the scene in the tomb of Meryre II was one of the boxing scenes in Ancient Egypt. ${ }^{4}$ There was no hieroglyphic caption. A man is shown punching another man's face, ${ }^{5}$ while the other fights the punch back with his hand, in a move regularly seen nowadays (Fig. 11). The match was watched by the pharaoh himself. For Touny, this scene did not depict boxers, but wrestlers. ${ }^{6}$ Decker discussed the absence of an audience for boxing as a sporting competition in ancient Egyptian sources ${ }^{7}$. Finally, This may be considered one of the earliest depictions of boxing as the boxers assume the same positions as modern professional boxers.

\footnotetext{
${ }^{1}$ PM IV: 212-214; Davies, N.,The Rock Tombs of El-Amarna, part II, 34; pl. xxxviii

${ }^{2}$ Gnirs ," In the King's House: Audiences and receptions at court", in: R. Gundlach\& T. Tylor (eds.), Königtum, Staat und gesellschaft früher Hochkulturen, $4^{\text {th }}$ Symposium on Egyptian Royal Ideology, Egyptian Royal Residences,31, fig.2.

${ }^{3}$ Saleh, Education in Ancient Egypt(in Arabic),117,fig.38

${ }^{4}$ Decker \& Tuillier, Le Sport Dans L'Antiquité, Égypt, Grèce et Rome, 47.

${ }^{5}$ Decker,"Boxen", LÄI, 847.

${ }^{6}$ Touny, Der Sport im alten Ägypten , 24.

${ }^{7}$ Decker, Zuschauer beim altägyptischen Sport, in: Scribe of Justice, Cahier No.42, in: Z. Hawas \& K. Daoud \& R. Hussein (eds.), Egyptological Studies in Honor of Shafik Allam, 119-126.
} 


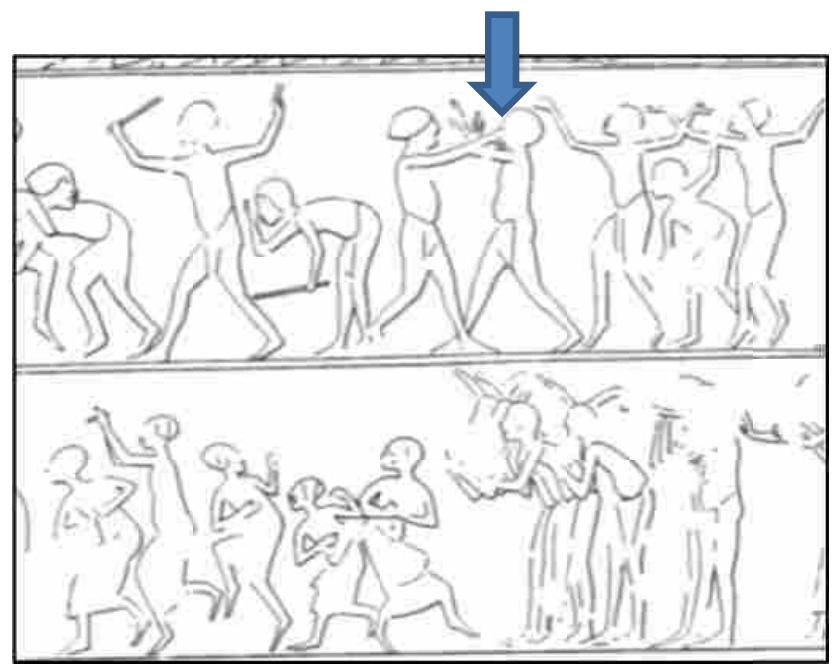

Fig. 11: Scene of two boxers on the middle of the upper register, tomb of Meryre II, Tell elAmarna, Eighteenth Dynasty (Davies, N. de G. M., The Rock Tombs of El-Amarna, part II, 34, pl. xxxviii)

\subsection{TERRACOTTA RELIEF FROM MEMPHIS $\left(1^{\mathrm{ST}}-2^{\mathrm{ND}}\right.$ CENTURY AD):}

A terracotta relief from Memphis, dating to the Greek-Roman period in Egypt, in the first or second century $\mathrm{AD},{ }^{1}$ is thought by $\mathrm{M}$. Mogensen to show a boxing match between a cat and a mouse. However, It is now conserved in Copenhagen Museum ${ }^{2}$ (Fig. 12). Fighting between cat and mouse was a popular subject in ancient Egyptian art. $^{3}$ The cat and mouse were standing on their hind legs, ready to fight the other. Both Both wear boxing gloves on their front paws, while an eagle flies high, holding in his talon the palm frond of victory. It is a comical portrayal of a boxing match between animals in ancient Egypt. ${ }^{4}$ It can remind of the figurative ostraca of animals of Deir el el Medina in the $21^{\text {st }}$ dynasty at the Museum of Turin. ${ }^{5}$ This is the first apparition of gloves in Egyptian depictions, later than in Mesopotamia, as they appeared in the third millennium BCE. Therefore, the appearance of gloves in Mesopotamia predated that in Egypt.

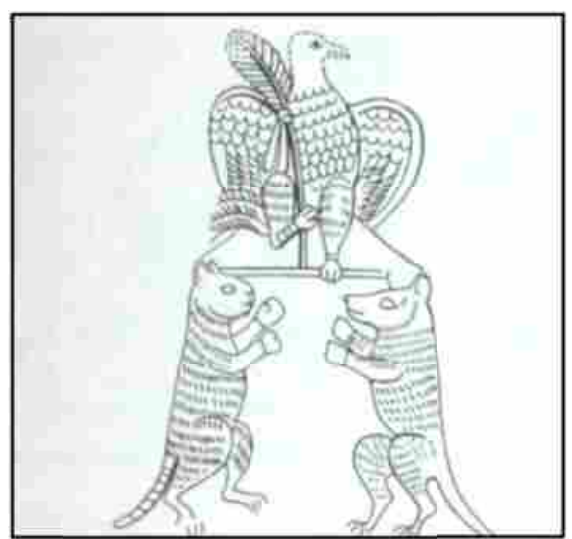

Fig. 12: Terracotta relief of a boxing match between cat and mouse from Memphis, Copenhagen Museum (Touny 1969: 195, abb.12).

\footnotetext{
${ }^{1}$ Mogensen, Z̈̈S 57, 87.

${ }^{2}$ Decker, and Others, Bildatlas zum Sport im alten Ägypten, 272; taf. cccxxii, n3

${ }^{3}$ Touny, Der Sport im alten Ägypten, 195; abb.12.

${ }^{4}$ Mogensen ,"Ein altägyptischer Boxkampf", 87-8.

${ }^{5}$ http://www.deirelmedina.com/lenka/Turinostraka.html
} 


\section{CONCLUSIONS}

Boxing in Mesopotamia has evidence that predates that originating from Egyptian contexts. It is depicted as a sport with regulations in the Sumerian and later cultures of Mesopotamia. The earliest scene from Egypt is found in the Fifth Dynasty tomb of Ptahhotep, with people training for a sport that resembles boxing. This may be the oldest evidence of boxing training in ancient Egypt. If true, this means that Egypt knew boxing after Mesopotamia. According to the available evidence, the fact remains that this sport was practiced in Mesopotamia centuries before Ancient Egypt. The tomb of Kheruef, TT 192 in the Theban necropolis holds the first clear evidence of boxing as sport in ancient Egypt (Figs. 7-9). It remains as yet unknown whether boxing as a sport was imported from Mesopotamia to Egypt; the present author thinks this is possible (Tables 1-2).

The appearance of gloves in Mesopotamia predates that in Egypt. Gloves appeared in the Early Dynastic Sumerian period in the third millennium BCE in Ancient Mesopotamian (Figs.1, 3 ,5). The boxers on the terracotta relief from Eshnunna have straps or bands around their wrists for support and protection (Fig. 5). There is no evidence that the boxers in Egyptian scenes were depicted wearing gloves, except for the scene from Memphis, dating back to the Greco-Roman Period (Fig. 12) kept at the Museum of Copenhagen. This first apparition in Egypt of gloves is more likely to be due to the Greek boxers than the Mesopotamian boxers. Sources of Greek-Roman period report that boxers wore gloves/straps.

Some depictions of boxing in Mesopotamia, dating back to the third and second millennia, show that it was accompanied by music, either a harp or a drum (Figs. 1, 2, 5). On the contrary, there is no evidence that boxing was accompanied by music in Ancient Egypt.

TABLE 1: COMPARISON BETWEEN EARLY BOXING REPRESENTATIONS IN ANCIENT EGYPT AND MESOPOTAMIA IN THE THIRD MILLENNIUM BCE.

\begin{tabular}{|l|l|l|l|l|l|l|}
\hline Origin & Scene & Date & Gloves & Music & Trainer & $\begin{array}{l}\text { Boxing } \\
\text { scene }\end{array}$ \\
\hline $\begin{array}{l}\text { Iraq } \\
\text { Museum, } \\
\text { No. 9012 }\end{array}$ & $\begin{array}{l}\text { Stone plaque } \\
\text { (Figs. 1-2) }\end{array}$ & $\begin{array}{l}\text { Early Dynastic } \\
\text { period (3000- } \\
\text { 2350 BCE.) }\end{array}$ & Yes & Yes & Yes? & Yes \\
\hline $\begin{array}{l}\text { Nintu } \\
\text { Temple, } \\
\text { Khafaji }\end{array}$ & $\begin{array}{l}\text { Terracotta } \\
\text { fragment }\end{array}$ & $\begin{array}{l}\text { Early Dynastic } \\
\text { period (3000- } \\
\text { (Fig. 3) }\end{array}$ & No & No & No & Yes \\
\hline Saqqara & $\begin{array}{l}\text { Mastaba of } \\
\text { Ptahhotep II }\end{array}$ & $\begin{array}{l}\text { Old Kingdom, 5 } \\
\text { Dynasty (2560- } \\
\text { 2420 BCE.) }\end{array}$ & No & No & Yes? & yes \\
(Fig. 6) & & & & \\
\hline
\end{tabular}

TABLE 2: COMPARISON BETWEEN EARLY BOXING

REPRESENTATIONS IN ANCIENT EGYPT AND MESOPOTAMIA IN THE

SECOND MILLENNIUM BCE.

\begin{tabular}{|l|l|l|l|l|l|l|}
\hline Origin & Scene & Date & Gloves/ & Music & Trainer & Boxing \\
\hline
\end{tabular}

- 83 - Boxing In Ancient Egypt And Mesopotamia 


\begin{tabular}{|c|c|c|c|c|c|c|}
\hline & & & straps & & & scene \\
\hline $\begin{array}{l}\text { Thebes- El- } \\
\text { Assasif. }\end{array}$ & $\begin{array}{l}\text { tomb of } \\
\text { Kheruef (TT } \\
\text { 192) (Figs. } \\
7-9)\end{array}$ & $\begin{array}{l}\text { Amenhotep III } \\
(1390-1352 \text { BCE.) }\end{array}$ & No & No & No & Yes \\
\hline Eshnunna, & $\begin{array}{l}\text { Terracotta } \\
\text { relief (Fig. } \\
\text { 4). }\end{array}$ & $\begin{array}{l}\text { about the third or } \\
\text { second } \\
\text { millennium BCE }\end{array}$ & yes & No & No & Yes \\
\hline $\begin{array}{l}\text { Tell el- } \\
\text { Amarna }\end{array}$ & $\begin{array}{l}\text { Tomb of } \\
\text { Meryre II - } \\
\text { (Figs. 10-11) }\end{array}$ & $\begin{array}{l}\text { Akhenaten (1351- } \\
1336 \text { BCE). }\end{array}$ & No & No & No & yes \\
\hline $\begin{array}{l}\text { Larsa/ British } \\
\text { Museum } \\
\text { (BM. 91906) }\end{array}$ & $\begin{array}{l}\text { A Terracotta } \\
\text { relief (Fig. } \\
5 \text { ) }\end{array}$ & $\begin{array}{l}\text { Old Babylonian } \\
\text { Period }(2000- \\
\text { 1595BCE.) }\end{array}$ & yes & yes & No & yes \\
\hline
\end{tabular}

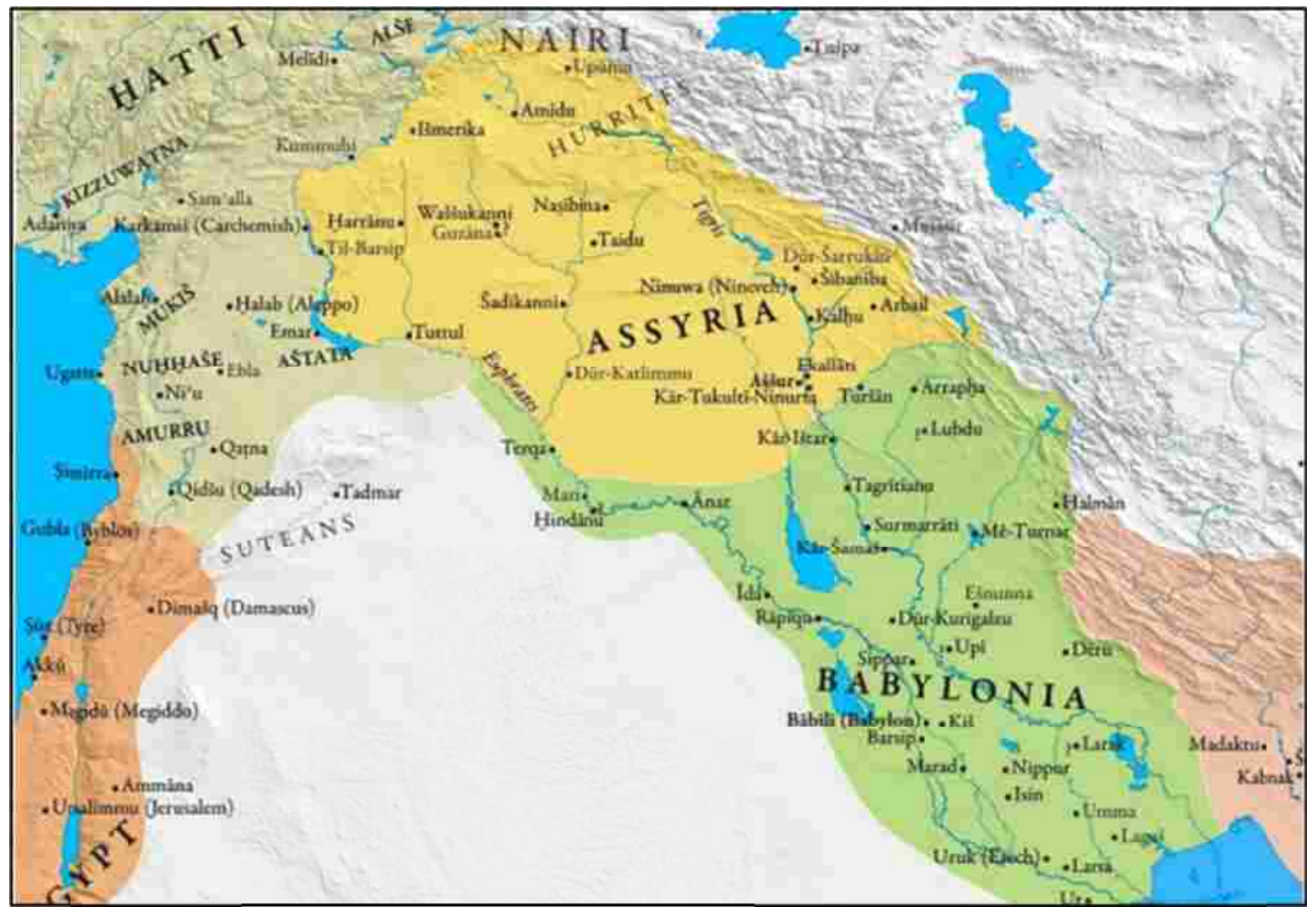

Map 1, Ancient Mesopotamia (https://edsitement.neh.gov/lesson-plans/cuneiform-writing-systemancient-mesopotamia-emergence-and-evolution) 


\section{BIBLIOGRAPHY}

1. Bienkowski, P. \& Millard, A. "Sport", in British Museum Dictionary of the Ancient Near East, British Museum press, London, (2000).

2. Caminos, R.A. Review of Kheruef Tomb, JEA 71, (1985),197-200.

3. Davies, N. de G. M. The Mastaba of Ptahhotep and Akhethotep at Saqqara, part I, London, (1900).

4.

The Rock Tombs of El-Amarna, part II, The Tombs of

Panehsy and Meryre II, Egypt Exploration fund, ASE 14, London, (1905).

5. Decker, W . "Boxen", LÄI, Wiesbaden, (1975), 847.

6. "Sport", $L \ddot{A} V$, Wiesbaden, (1984), 1162-70.

7. - __ Sport Und Spiel im Alten Ägypten, München, (1987).

8. Sports and Games of Ancient Egypt, Sport and History Series,

Translated by Allen Guttmann, The American University in Cairo press, Cairo, (1993).

9. Pharao und Sport, Zaberns Bildbände zur Archäologie, Mainz, (2006).

10. Zuschauer beim altägyptischen Sport, in: Scribe of Justice, Cahier No.42, Egyptological Studies in Honour of Shafik Allam, edited by: Z. Hawas \& K. Daoud \& R. Hussein, Le Caire, (2011), 119-126.

11. \& Herb, M. \& Brill, E.J. Bildatlas Zum Sport im Alten Ägypten, Corpus der Bildlichen Quellen zu Leibsübungen,Teil 1,2, Handbuch, Der Orientalistik 14, Leiden, New York, Köln, (1994).

12. \& Förster, F. Annotierte Bibliograghie Zum Sport im Alten Ägypten II: 1978-2000, im: Nikephoros Beihefte 8, Berlin , (2002).

13. \& Tuillier, J.-P. Le Sport Dans L'Antiquité, Egypte, Grèce et Rome, Antiqua 8, Paris, (2004), 47-8.

14. Department of Antiquities, A Guide of the collection in the Iraq Museum, Baghdad, (1937).

15. De Varies, C. Attitudes of the Ancient Egyptians toward physical-recreative activities, in: UMI dissertation services (A Dissertation Submitted to the Faculty of The Division of the Humanities in Candidacy for the degree of Doctor of Philosophy Department of Oriental Languages and Civilizations), Chicago, (1960),222-239.

16. Dodson, A. \& Ikram, S. The Tombs in Ancient Egypt, The American University in Cairo press, (2008).

17. Essche, E.U. "Le Chat dans les fables et les contes: Les guerre entre chats et Souris, Le monde retourné", in: Les Divins chats d'Égypte, Parfum Lettres Orientales 3, éds. Par: L. Delvaux, E. Warmenbol, Leuven, (1991), 69-83.

18. Festuccia, S. "Sport Representation: Transfer Images of Agonistic Contests", in: proceeding of International Congress on the Archaeology of the 9 th International congress on the Archaeology, vol. I, Wiesbaden, (2016), 99-110.

19. Gnirs, A.M." In the King's House: Audiences and receptions at court", in: Königtum, Staat und gesellschaft früher Hochkulturen, $4^{\text {th }}$ Symposium on Egyptian Royal Ideology, Egyptian Royal Residences, edited by Gundlach, R.\& Tylor, T.H., Weisbaden, (2009),13-43.

20. Griffiths, J. G. A Refrain in the texts of The Edfu Temple, JEA 62, (1976), 186-187. 
21. Mogensen, M., "Ein Altägyptischer Boxkampf ", Z̈̈S 57, Leipzig, Berlin, (1922), 87-88.

22. Murry, S. R. "Boxing Gloves of the Ancient World", Journal of combative sport,in:(https://www.academia.edu/3728745/Boxing_Gloves of the Ancient World).pdf,(2010), 1-23.

23. Moortgat A., Art in Ancient Iraq, translated into Arabic by Essa Salman and Salim Taha Al-Takriti, Baghdad, (1975).

24. Orthmann, W. Der Alte Orient, $P K G$ 14, Berlin, (1975).

25. Porter, B. \& Moss, R.L.B. Topographical Bibliography of Ancient Egyptian Hieroglyphic Text, Reliefs, and Paintings, The Theban Necropolis, part I, Private Tombs, Second edition, Griffith Institute Ashmolean Museum, Oxford, (1994).

26.

Topographical Bibliography of Ancient Egyptian Hieroglyphic Text, Reliefs, and Paintings, Lower and Middle Egypt, part IV, Griffith Institute Ashmolean Museum, Oxford, (1994).

27. Rolling, R. "Sport Und Spiel" in: Reallexikon der Assyriologie, und vorderasiatischen Archäologie, band 13, edited by Erich, E. \& Friedrich, R., Berlin, (2011-2013), 6-16.

28. Saleh, A.A. Education in Ancient Egypt (in Arabic), Cairo, (1966).

29. The Epigraphic Survey, The Tomb of Kheruef, Theban Tomb 192, OIP 102, Chicago, (1980).

30. Touny, A.D. Der Sport im Alten Ägypten, International Olympic Editions, Stuttgart, (1969).

31. Tyldesley, J. Egyptian Games and sports, A Shire Egyptology book 29, Malta, (2007). 